\title{
SEASONAL VARIATIONS IN PRIMARY PRODUCTIVITY AND ITS RELATION TO SOME PHYSICO-CHEMICAL PROPERTIES OF WATER AT AL-ABBASSA FISH FARM
}

\author{
Amany A. Mohammed*, Entesar A. Ahmed**, Samir M. Saeed*, Aida M. Dawah*, Rawheya A. \\ Salah El Din** \\ * Limnology Department, Central Laboratory for Aquaculture Research, Agricultural Research \\ Center, Egypt. \\ **Botany and Microbiology Department, Faculty of Science, Al-Azhar University (Girls Branch), \\ Nasr City, Cairo, Egypt
}

\begin{abstract}
The present study was carried out to evaluate the primary productivity (gross, net and respiration) and its relation to some water quality parameters at Al-Abbassa fish farm (inlet, outlet and the fish ponds) and Ismailia canal which is the main feeder of this area. The study extended from April, 2014 to May, 2015. Physicochemical parameters, gross primary production (GPP), net primary production (NPP) and community respiration (CR) were measured through dissolved oxygen determination in situ and laboratory. The results showed that, the Physico- chemical parameters of water were significantly different among different seasons and the studied sites. Concerning BOD annual mean results, all the studied sites are located in the clean range. Results of (GPP), (NPP) and (CR) are higher in the fishponds compared to the other studied sites. It is concluded that the primary productivity and trophic nature were affected by increased levels of nutrients in fish ponds, where they exhibited a heterotrophic nature compared to the other sites.
\end{abstract}

Key words: CR, fish ponds, GPP, NPP, primary productivity.

\section{INTRODUCTION}

Primary production refers to the amount of organic matter synthesized from inorganic materials through photosynthesis. Primary producers are organisms able to use inorganic carbon through the process of photosynthesis to build organic matter. Nutrients and light (solar energy) are considered the main limiting factors to primary production in an aquatic ecosystem (Simmons et al., 2004). In aquatic ecosystems, primary producers are represented by autotrophs (algae, planktons, etc.) on which all the life forms depend (Ogbuagua and Ayoade, 2011) and are the base of the food chain.

Measurement of primary production is necessary to understand the trophic status to evaluate the fish production potential of aquatic ecosystem (Melack, 1976; McConnell et al., 1988). Also, primary productivity is helpful to understand food web and food chain (Chinnaiah and Madhu, 2010), pollution study (Prabhakar et al., 2009) and water quality (Wetzel and Linkens, 2000).
The primary and secondary productivity of a fresh water ecosystem depend on its surroundings, seasons and an array of biotic and abiotic factors. The composition and function of aquatic organisms reflect physico chemical conditions of water (Karr, 1991). Primary production can be distinguished as net primary productivity (NPP) or gross primary productivity (GPP), where GPP includes the total amount of fixed carbon(organic matter) plus the rate of respiration, while NPP accounts for the rate of organic matter synthesized through photosynthesis minus the rate lost through respiration and excretion. In this study, some water properties at Al-Abbassa fish farm (fish ponds as well as their inlet and outlet) and the main water supply for this area (Ismailia canal) were determined through a year to investigate their impact on the primary productivity of water and identified the major water factors responsible for variations in gross production of primary producers which considered the main natural food for fish. 


\section{MATERIALS AND METHODS}

\section{Sampling sites}

Water samples were collected from four sampling sites at Al-Abbassa fish farm (the World Fish Center), and Ismailia canal including four sites namely; 1-Ismailia canal site $\mathrm{A}$, which is the main feeder (MF) for the area and the fish farm; 2- the irrigation canal (Inlet), site B, which supplies fish ponds with mixed water (Nile and underground water); 3the fish ponds (site $\mathrm{C}$ ) which receive different inputs as feed and organic fertilizers and 4- the drainage canal (outlet), site $\mathrm{D}$, where water is discharged from the fish farm as shown in figure (1).

\section{Sampling and laboratory analysis}

Water samples were taken monthly (from April, 2014 to May, 2015) at different sites to estimate physico-chemical properties and primary productivity. Water samples were taken with a water sampler constructed from a PVC pipe (5-cm diameter, $1.5-\mathrm{m}$ long) from at least five spots between 10.00 am and $12.00 \mathrm{pm}$ at a depth of $30 \mathrm{~cm}$ below the water surface and mixed well in a plastic container. Then one liter of water samples was taken in plastic bottle for chemical analysis. Water temperature and $\mathrm{pH}$ were measured directly at the sampling site by portable Multi-parameter ( $\mathrm{pH} / \mathrm{EC} / \mathrm{TDS} / \mathrm{Salt}$ ), PCSTestr 35 (Singapore). Dissolved oxygen concentration and biological oxygen demand were determined by the modified Winkler method (APHA, 1998). Water transparency (cm) was measured by using a Secchi Disc (20 $\mathrm{cm}$ in diameter crossed by white and black color).The concentration $(\mathrm{mg} / \mathrm{l})$ of alkalinity (carbonate and bicarbonate as $\mathrm{CaCO}_{3}$ ) and inorganic carbon as well as chlorophyll"a" content $(\mu \mathrm{g} / \mathrm{l})$ were measured by the methods described in Boyd and Tucker (1992). Measurements of primary productivity (GPP,NPP and CR) were determined from changes in DO in situ using the BOD light and dark bottle method described by APHA (1998) and Wetzel and Likens (2000).

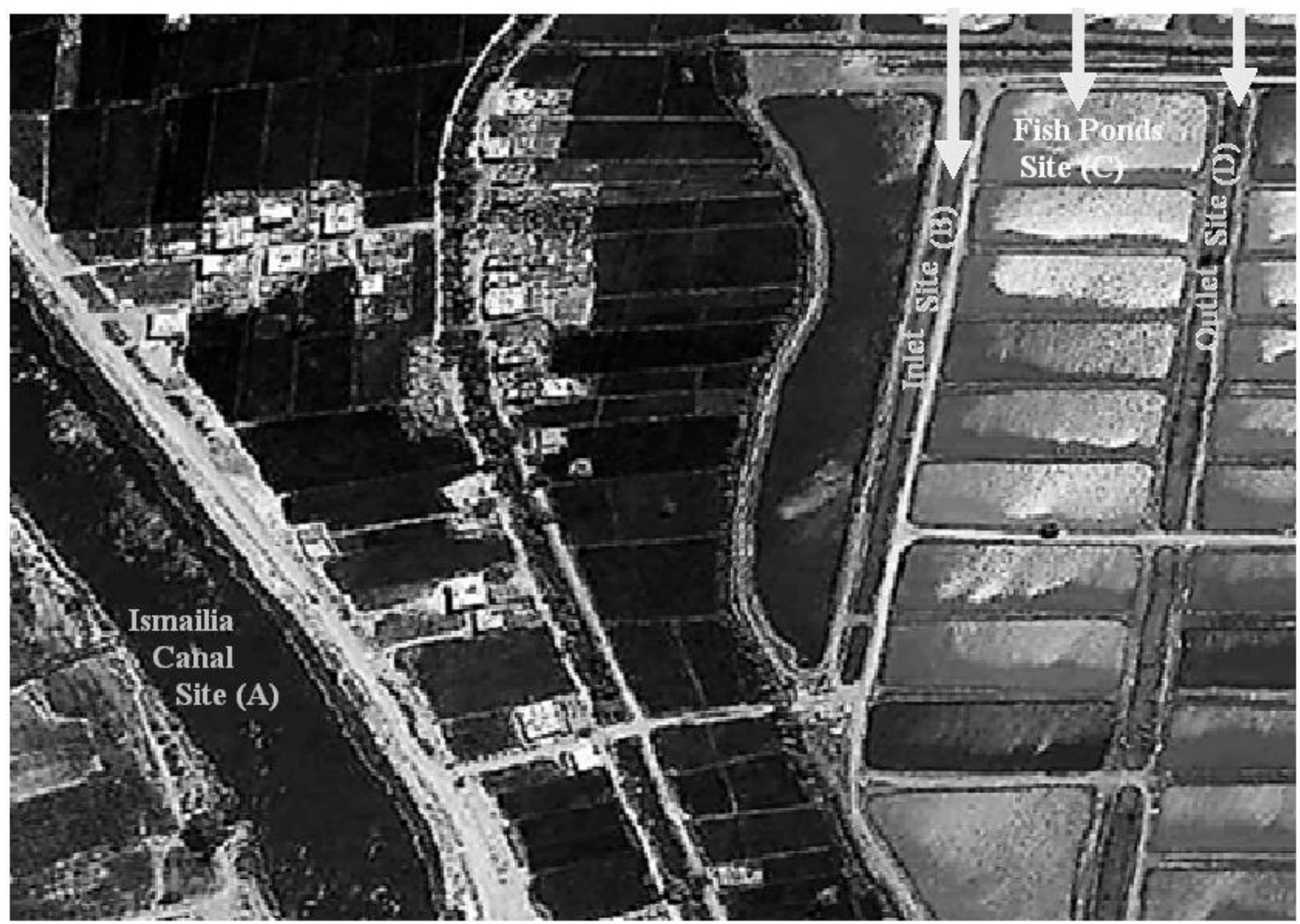

Figure (1): Map demonstrates the location of Al-Abbassa fish farm at the World Fish Center and Ismailia canal. 
-Production/Respiration Ratio $(\mathrm{P} / \mathrm{R})=\mathrm{GPP} / \mathrm{CR}_{24}$,

Where, CR24 = community respiration during 24 hours.

-Net daily metabolism $(\mathrm{NDM})=\mathrm{GPP}-\mathrm{CR}_{24}$

\section{Statistical analysis}

Statistical analysis was performed using the analysis of variance (ANOVA) and Duncan's Multiple Range Test to determine differences between spatial and seasonal means at a significance level of $\mathrm{p}<0.05$. Standard errors were also estimated (Dytham, 1999).

\section{RESULTS AND DISCUSSION}

The seasonal variations of water quality parameters at different sites are illustrated in table (1). All physical, chemical and biological properties are governed by temperature so; it considered one of the most important parameters of the aquatic habitats. It influences the oxygen content of water through the rate of photosynthesis (Barnabe, 1994). Temperature not significantly different among different sites whereas, it shows significant differences $(\mathrm{P}<0.05)$ among seasons. The highest water temperature value $\left(30.3^{\circ} \mathbf{C} \pm 0.29\right)$ was recorded at site (D) during summer and the higher degree may be due to great solar radiation and clear atmosphere. On the other hand, the lowest temperature value $\left(17.5^{\circ} \mathbf{C} \pm 1.40\right)$ was observed at site (A) during winter. Low water temperature during winter is due to high current velocity, frequent clouds and high humidity (Shama et al., 2011). This in agreement with Khalil et al. (2012) who found that water temperature was $17.78^{\circ} \mathrm{C}$ at Ismailia canal water during winter season.

It was observed that, the $\mathrm{pH}$ was in the alkaline side at all the studied sites. Seasonally, the highest $\mathrm{pH}$ value (8.78) was reported at site (C) during autumn, while the lowest one (7.96) was observed at site (B) and (A) during winter, There are significant differences $(\mathrm{P}<0.05)$ among different seasons. The total annual means of $\mathrm{pH}$ were $8.2,8.04,8.56$ and 8.32 at sites A, B, C and D, respectively. According to Santhosh and Singh (2007) the ideal $\mathrm{pH}$ range for fish culture is between7.5 and 8.5, the suitable $\mathrm{pH}$ level for fish culture is between 6.7 and 9.5 and above and below this is stressful

Table (1): Range and annual means of water quality variables at the studied sites.

\begin{tabular}{|c|c|c|c|c|}
\hline \multirow{2}{*}{ Parameter } & $\begin{array}{c}\text { Site A } \\
\text { (Main feeder) }\end{array}$ & $\begin{array}{c}\text { Site B } \\
\text { (Inlet) }\end{array}$ & $\begin{array}{c}\text { Site C } \\
\text { (Fishponds) }\end{array}$ & $\begin{array}{c}\text { Site D } \\
\text { (Outlet) }\end{array}$ \\
\hline \multirow{2}{*}{ Temperature $\left({ }^{\circ} \mathrm{C}\right)$} & $17.5-29.5$ & $20.1-28.3$ & $18.8-30.1$ & $19.1-30.3$ \\
& $24.1^{\mathrm{A}}$ & $24.3^{\mathrm{A}}$ & $24.3^{\mathrm{A}}$ & $24.6^{\mathrm{A}}$ \\
\hline \multirow{2}{*}{$\mathrm{pH}$} & $7.9-8.3$ & $7.9-8.1$ & $8.2-8.7$ & $8.15-8.4$ \\
& $8.2^{\mathrm{B}}$ & $8.0^{\mathrm{C}}$ & $8.5^{\mathrm{A}}$ & $8.3^{\mathrm{AB}}$ \\
\hline \multirow{2}{*}{ Dissolved oxygen $(\mathrm{mg} / \mathrm{l})$} & $6.04-11.9$ & $3.9-10.9$ & $7.4-8.8$ & $5.8-10.0$ \\
\hline Transparency $(\mathrm{cm})$ & $9.4^{\mathrm{A}}$ & $7.5^{\mathrm{A}}$ & $7.7^{\mathrm{A}}$ & $8.0^{\mathrm{A}}$ \\
\hline \multirow{2}{*}{ Biological oxygen demand $(\mathrm{mg} / \mathrm{l})$} & $84.6-94.4$ & $17.4-25.5$ & $14.6-15.6$ & $12.4-15.4$ \\
& $88.9^{\mathrm{A}}$ & $20.1^{\mathrm{B}}$ & $15.3^{\mathrm{C}}$ & $13.8^{\mathrm{C}}$ \\
\hline \multirow{2}{*}{ Total alkalinity $(\mathrm{mg} / \mathrm{l})$} & $0.7-1.5$ & $0.8-1.5$ & $1.0-2.4$ & $1.0-2.2$ \\
& $1.1^{\mathrm{A}}$ & $1.1^{\mathrm{A}}$ & $1.8^{\mathrm{A}}$ & $1.6^{\mathrm{A}}$ \\
\hline Inorganic carbon(mg/l) & $159.8-199.7$ & $168.6-216.3$ & $193.7-255.3$ & $210.6-265.7$ \\
& $173.5^{\mathrm{B}}$ & $188.0^{\mathrm{B}}$ & $228.6^{\mathrm{A}}$ & $227.6^{\mathrm{A}}$ \\
\hline \multirow{2}{*}{ Phyt.biomass(Chl-"a") $(\mu \mathrm{g} / \mathrm{ll})$} & $37.6-46.8$ & $40.3-52$ & $47.2-59.1$ & $48.7-62.6$ \\
& $40.9^{\mathrm{B}}$ & $45.0^{\mathrm{B}}$ & $53.3^{\mathrm{A}}$ & $53.9^{\mathrm{A}}$ \\
\hline
\end{tabular}

Significant level at $\mathrm{p}<0.05$. 
for fish. Devis (1955) reported that $\mathrm{pH}$ may be used as an indicator of aquatic production. $\mathrm{pH}$ values largely controlled by photosynthetic activities (Boyd, 1998) specially $\mathrm{CO}_{2}$ equilibrium state in water $\left(\mathrm{CO}_{2}+\mathrm{CO}_{3}+\mathrm{H}_{2} \mathrm{O}=\right.$ $\left.2 \mathrm{HCO}_{3}\right) . \quad \mathrm{CO}_{2}$ is being utilized during photosynthesis. Increase of $\mathrm{pH}$ may be the result of high photosynthetic activity of aquatic plants and phytoplankton (Shiddamallayya \& Pratima, 2008).

Perhaps, the decrease in $\mathrm{pH}$ level may be due to the decrease of phytoplankton density during winter and the decomposition of organic matter (Toufeek and Korium, 2015). Temperature, carbonate and bicarbonate system and the photosynthetic activity of the primary producers are the main factors which affect the seasonal variations in $\mathrm{pH}$ (Abdo, 2005). Khaiwal et al. (2003) mentioned that the high primary productivity promoting factor is considered to be the alkaline $\mathrm{pH}$.

Concerning, fluctuations in dissolved oxygen concentrations, at the studied sites, there were significant differences $(\mathrm{P}<0.05)$ among different seasons, since the highest concentration $(11.9 \mathrm{mg} / \mathrm{l})$ was recorded at site A during winter, while the lowest one (3.91 $\mathrm{mg} / \mathrm{l})$ was detected at site B during summer. The total annual means were 9.44, 7.53, 7.72 and $8.0 \mathrm{mg} / \mathrm{l}$ at sites A,B,C and D, respectively. It is observed that dissolved oxygen is inversely proportional to temperature and these results are in agreement with the results of Abd ElMonem (2008) who reported that, spatial distribution of DO along the water column showed that oxygen distribution has an opposite trend with that of temperature. The decrease in DO in summer might be due to the elevation of water temperature, decrease in photosynthesis and the increase in oxidative processes of organic matter (Abdel-Satar, 2005; Elewa et al., 2007). Niusha et al. (2014) mentioned that the increase of DO during winter season might be due to the cumulative effect of higher wind velocity coupled with heavy rainfall and the resultant freshwater mixing.
Transparency of water in aquatic ecosystem especially in ponds are largely influenced by the biotic communities present. The highest SD reading $(94.4 \mathrm{~cm})$ was observed at site (A) during winter, while the lowest one $(12.4 \mathrm{~cm})$ was recorded at site (D) during autumn. The maximum transparency recorded in Ismailia canal (site A) may be attributed to the increase of water level in the canal. Perhaps, the transparency was lower in the autumn season at sites (B, C and D) due to high planktonic population. The decrease in SD readings (14.6$15.6 \mathrm{~cm}$ ) at site $\mathrm{C}$ (fishponds) was mainly caused by the abundance of phytoplankton populations and suspended matter (clay and organic materials) (Ferdoushi et al., 2008) that result from sediment turbulence by fish and also the water level compared to Ismailia canal. The annual averages of SD readings showed that, there are significant differences $(\mathrm{P}<0.05)$ among the studied locations, where the total annual means were $88.9,20.1,15.3$ and $13.8 \mathrm{~cm}$ at sites A, B, C and D, respectively. Generally a transparency of greater than $45 \mathrm{~cm}$ or less than $15 \mathrm{~cm}$ is considered unsuitable for fish culture operations (ICAR, 2011).

Seasonally, BOD shows fluctuations, where the highest $(2.40 \mathrm{mg} / \mathrm{l})$ concentration was recorded at site $(\mathrm{C})$ during summer, while the lowest one $(0.76 \mathrm{mg} / \mathrm{l})$ was detected at site (A) during autumn. Moncrief and Jones (1977) reported that oxygen consumption increase as temperature increase. They also recorded that a $10^{\circ} \mathrm{C}$ increase of temperature roughly doubles biochemical rate.

Physiological stress to phytoplankton, zooplankton and fish is due to high temperature, which not only causes reduction of oxygen availability, but also increases oxygen demand (Sharma and Selvaraj, 2000).

The total annual means of BOD were 1.12, $1.13,1.84$ and $1.61 \mathrm{mg} / \mathrm{l}$ at sites $\mathrm{A}, \mathrm{B}, \mathrm{C}$ and $\mathrm{D}$, respectively. Biological oxygen demand (BOD) is a measure of oxygen required by microbes to degrade the organic matter under aerobic condition. High BOD depletes the oxygen level to a critical condition thus indicating the 
pollution status of waters. Depletion of DO in water is due to high amount of organic matter under going biological degradation (RimRukeh et al., 2006). According to Ekubo and Abowei (2011) the aquatic system with BOD levels between 1.0 and $2.0 \mathrm{mg} \mathrm{L}^{-1}$ considered clean; $3.0 \mathrm{mg} \mathrm{L}^{-1}$ fairly clean; $5.0 \mathrm{mg} \mathrm{L}^{-1}$ doubtful and $10.0 \mathrm{mg} \mathrm{L}^{-1}$ definitely bad and polluted. It is concluded from the annual averages of the present study that, all the studied sites located in the clean range.

Alkalinity in most natural water is the function of bicarbonate and carbonates. It is also used as a measure of productivity (Boyd, 1998).Total alkalinity fluctuates seasonally and there are significant differences among different seasons, where it ranged between $159.8 \mathrm{mg} / \mathrm{l}$ at site (A) in summer and 265.7 $\mathrm{mg} / \mathrm{l}$ at site (D) in autumn. Higher concentrations of total alkalinity may be attributed to increase in photosynthetic activity (Raina et al., 2013). The annual averages of total alkalinity showed that there are significant differences among the studied sites, where the highest value was recorded at sites $\mathrm{C}$ and $\mathrm{D}$, while the lowest values were detected at sites (A) and (B). Boyd (1990) stated that higher concentration of total alkalinity may be due to increase of carbonate through photosynthetic activity which leads to the consumption of carbon dioxide and hydrolysis of bicarbonate. The degradation of plants, other organisms and organic wastes might also be one of the reasons for the increase in bicarbonate, where bicarbonate is the final product of the decomposition and in turn the total alkalinity (Jain et al., 1997; Chaurasia and Pandey, 2007).

Fluctuations in dissolved inorganic carbon (DIC) have the same trend of alkalinity. DIC is derived from the combined effects of the weathering of carbonate rocks and soils, together with microbial breakdown of organic matter which releases $\mathrm{CO}_{2}$. Seasonally, the lowest $(37.6 \mathrm{mg} / \mathrm{l})$ value of inorganic carbon was recorded at site (A) during summer, while the highest $(62.6 \pm 1.88 \mathrm{mg} / \mathrm{l})$ and $(59.1 \pm 1.5$ $\mathrm{mg} / \mathrm{l})$ values were reported during autumn at site (D) and (C), respectively. It was observed from the annual means that there are significant differences $(\mathrm{P}<0.05)$ among the studied sites, since the lowest values were detected at sites(A and $\mathrm{B}$ ), while the highest values were detected at sites (C and D).DIC plays a critical role in primary productivity, where it provides a bioavailable carbon source for aquatic plant photosynthesis (Sandjensen et al., 1992; Jones et al., 2002 and Maberly et al., 2015).

$\mathrm{Chl}$ "a" content indicates the phytoplankton biomass (George and Hurley, 2004). It gives an estimate about the amount of fish food organisms i.e. - plankton available in the water body. Seasonally, there are significant differences among different seasons, where the highest value $(311.06 \mu \mathrm{g} / \mathrm{l})$ was observed at site (C) during autumn, while the lowest one (20.9 $\mu \mathrm{g} / \mathrm{l}$ ) was detected at site (B )during winter. Availability of light energy to a fish pond greatly influences its productivity. Synthesis of carbohydrates is a photochemical process energized by light (Rath, 1993). It is shown that, the annual averages of chl"a" concentrations showed significant differences $(\mathrm{P}<0.05)$ among the studied sites and the lowest values were recorded at sites (A ) and (B), while the highest values were observed at sites $\mathrm{C}$ and D. El-Otify (2015) stated that phytoplankton biomass in terms of chlorophyll"a" concentrations were always of relatively higher values in fish ponds than in its water supply as chlorophyll- $a$ concentrations appeared to be promoted by sufficient nutrients. The increase in the levels of nutrients in fish ponds could be possibly caused by the occasional additions of organic and inorganic fertilizers.

Primary productivity can be determined by the oxygen production fluxes during short period of time per unit volume of water. Gross primary productivity is the total rate of photosynthesis including the organic matter utilizes in respiration during the period of measurement. This is also known as total photosynthesis or total assimilation. Figure (2) 
shows the fluctuations in gross primary productivity (GPP) at the studied sites. Seasonally, the highest GPP (489.8 \pm 112.1 $\left.\mathrm{mgC} / \mathrm{m}^{3} / \mathrm{h}\right)$ and $\left(419.9 \pm 101.2 \mathrm{mgC} / \mathrm{m}^{3} / \mathrm{h}\right)$ were recorded at site $(\mathrm{C})$ during summer and autumn, respectively, while the lowest one $(219.5 \pm 30.9$ $\mathrm{mgC} / \mathrm{m}^{3} / \mathrm{h}$ ) was recorded at site (A) during summer. It was observed that, site $\mathrm{C}$ has the highest phytoplankton density, so it showed the highest productivity. This finding is in accordance with Radwan (2005) who reported that water having less plankton concentration showed low productivity while, dense population of plankton indicating higher productivity. The higher rate of primary productivity during summer has also been reported by Datta and Bandhopadhay (1982). The highest rate of productivity during the summer may be due to bright sunshine with high temperature, high phytoplankton density and algal blooms. Also, Jana et al. (2012) reported that the positive effect of the manuring, leading to nutrient enrichment (especially phosphorus) and increasing of the primary productivity. The annual averages of GPP were $284.4 \pm 28.5,254.0 \pm 8.23,353.47 \pm$ 36.06 and $294.4 \pm 8.61 \mathrm{mgC} / \mathrm{m}^{3} / \mathrm{h}$ at site (A), (B), (C) and (D), respectively. Nutrient rich water habitats in fish ponds were characterized by relatively high primary production (Takamura et al., 1995). Enhancement of phytoplankton proliferation in these systems could be a function of the nutrient loads. (Table 2).

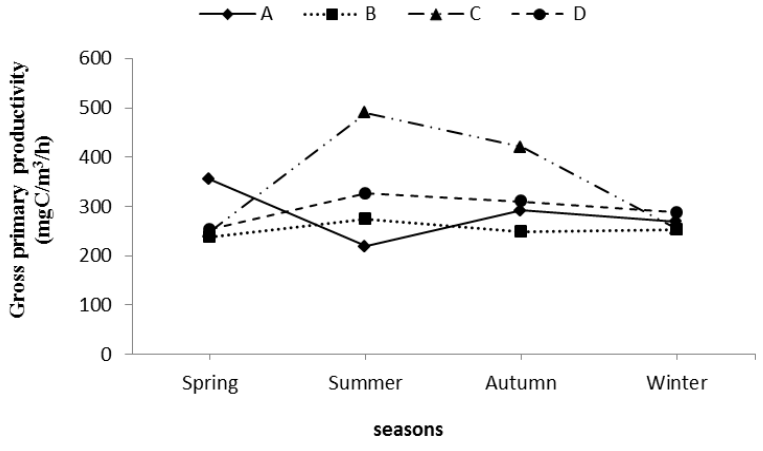

Fig. (2): Seasonal variations of gross primary productivity (GPP) of phytoplankton at the studied sites.

Net primary productivity is the rate of storage of organic matter in plant tissues in the excess of the respiratory use by the plants during the measurement period. This is also called as apparent photosynthesis or net assimilation.Net photosynthesis had an ecological effect because it represents the tangible quantity of organic matter added to the environment (Ryther, 1956). The conversion of GPP into NPP depends on a great extent of the amount of oxygen consumed by the particulate and dissolved organic matter (Edberg and Hofsten, 1973), microbial activity (Stewart $\boldsymbol{e t}$ al., 1977) or sediment (Rich, 1979). Data represented in figure (3) showed fluctuations in net primary productivity (NPP) at the studied sites. Seasonally, the lowest NPP value $(61.5 \pm$ $14.4 \mathrm{mgC} / \mathrm{m}^{3} / \mathrm{h}$ ) was observed at site (B) during spring, while the highest one (264.6 \pm 48.3 $\mathrm{mgC} / \mathrm{m}^{3} / \mathrm{h}$ ) was recorded at site (C) during

Table (2): Annual average of primary productivity components GPP, NPP, CR, P/R and NDM at the studied sites.

\begin{tabular}{|c|c|c|c|c|}
\hline Parameter & $\begin{array}{c}\text { Site A } \\
\text { (Main feeder) }\end{array}$ & $\begin{array}{c}\text { Site B } \\
\text { (Inlet) }\end{array}$ & $\begin{array}{c}\text { Site C } \\
\text { (Fishponds) }\end{array}$ & $\begin{array}{c}\text { Site D } \\
\text { (Outlet) }\end{array}$ \\
\hline $\begin{array}{c}\text { Gross primary productivity } \\
\text { (GPP) }\end{array}$ & $284.4^{\mathrm{A}} \pm 28.5$ & $254.0^{\mathrm{A}} \pm 8.2$ & $353.4^{\mathrm{A}} \pm 36.0$ & $294.4^{\mathrm{A}} \pm 8.6$ \\
\hline Net primary productivity (NPP) & $199.2^{\mathrm{A}} \pm 14.4$ & $117.7^{\mathrm{B}} \pm 21.8$ & $182.6^{\mathrm{AB}} \pm 28.4$ & $182.7^{\mathrm{AB}} \pm 22.2$ \\
\hline Community respiration (CR) & $137.7^{\mathrm{AB}} \pm 6.7$ & $114.04^{\mathrm{B}} \pm 12.2$ & $198.4^{\mathrm{A}} \pm 24.4$ & $166.06^{\mathrm{AB}} \pm 19.4$ \\
\hline $\begin{array}{c}\text { Gross primary productivity } \\
/ \text { Respiration (P/R) ratio }\end{array}$ & $1.26^{\mathrm{A}} \pm 0.29$ & $1.46^{\mathrm{A}} \pm 0.20$ & $0.88^{\mathrm{A}} \pm 0.05$ & $0.92^{\mathrm{A}} \pm 0.06$ \\
\hline $\begin{array}{c}\text { net daily metabolism } \\
(\text { NDM) }\end{array}$ & 106.6 & 511.1 & -599.0 & -452.6 \\
\hline
\end{tabular}

Significant level at $\mathrm{p}<0.05$. 
autumn. Concerning the annual average, there are significant differences $(\mathrm{P}<0.05)$ among different sites where the maximum value of NPP was $\left(199.2 \pm 14.4 \mathrm{mgC} / \mathrm{m}^{3} / \mathrm{h}\right)$ detected at site $(\mathrm{A})$, while the minimum one $(117.7 \pm 21.8$ $\mathrm{mgC} / \mathrm{m}^{3} / \mathrm{h}$ ) was at site (B ) (Table 2).

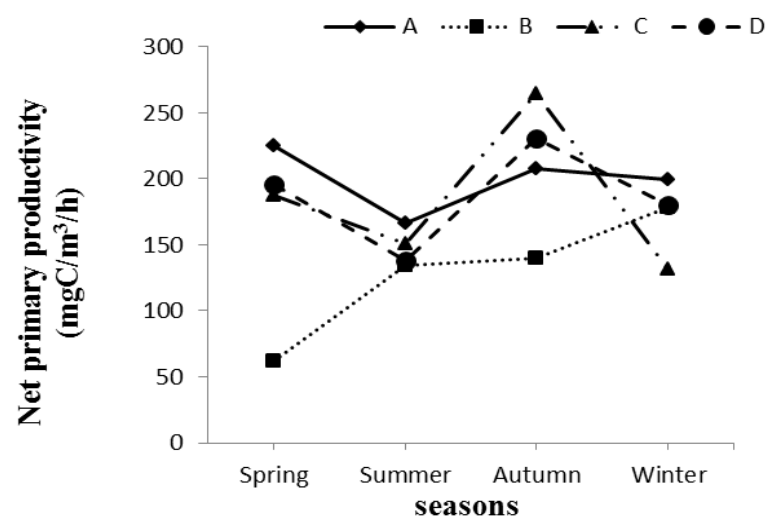

Fig. (3): Seasonal variations of net primary productivity (NPP) of phytoplankton at the studied sites.

As shown in figure (4), the lowest community respiration concentration $(89.6 \pm$ $21.9 \mathrm{mgC} / \mathrm{m}^{3} / \mathrm{h}$ ) was recorded at site (B) during winter, while the highest values $(254.4 \pm 59.2$ $\left.\mathrm{mg} \mathrm{C} / \mathrm{m}^{3} / \mathrm{h}\right)$ and $\left(246.1 \pm 60.1 \mathrm{mg} \mathrm{C} / \mathrm{m}^{3} / \mathrm{h}\right)$ were recorded at site $(\mathrm{C})$ during summer and autumn respectively. Nutrients enrichment has been shown to stimulate heterotrophic respiration by increasing autotrophic productivity (Suberkropp and Chauvet, 1995). Autotrophic production was likely contributing to concentrations of autochthonous organic matter and fueling autotrophic and heterotrophic respiration because both GPP and $\mathrm{CR}$ were positively correlated with algal biomass. High light levels and high concentrations of nutrients resulted in high algal biomass and hence high rates of GPP and $\mathrm{CR}$ at site (C). So, the majority of CR was due to the autochthonous (either directly through autotrophic respiration or indirectly by autotrophs providing organic matter for heterotrophic consumption).

The annual average of community respiration demonstrated that there are significant differences $(\mathrm{P}<0.05)$ among the studied sites, since the lowest $\mathrm{CR}$ concentration was $\left(114.04 \pm 12.2 \mathrm{mgC} / \mathrm{m}^{3} / \mathrm{h}\right)$ at site (B), whereas the highest concentration $(198.4 \pm 24.4$ $\mathrm{mg} \mathrm{C} / \mathrm{m}^{3} / \mathrm{h}$ ) was detected at site (C) (Table 2). Respiration is a continuous process and its rate is almost the same during the 24 hours. The high respiration of all living organisms reduces the dissolved oxygen content (Prabhakar $\boldsymbol{e t}$ al., 2009). This observation supports the present results, where the values of dissolved oxygen content were found lower and the respiration values were found higher during the summer season at site (D) and during summer and autumn at site (C).

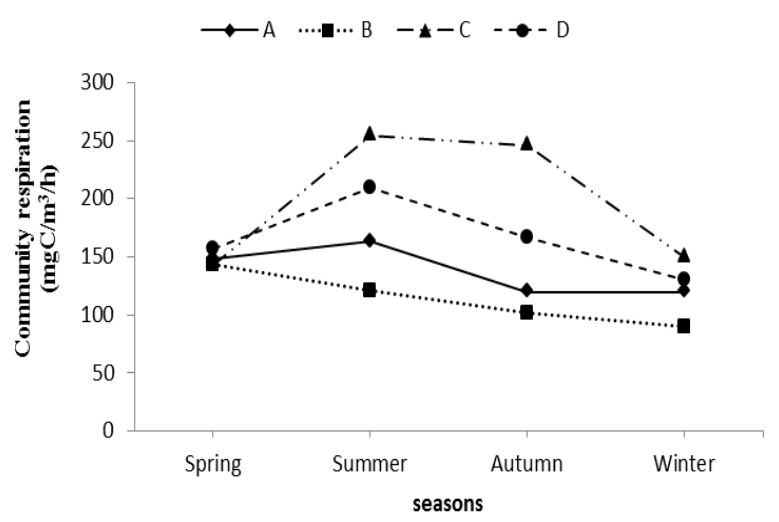

Fig. (4): Seasonal variations of community respiration $(C R)$ at the studied sites.

Figure (5) shows the fluctuations in gross primary productivity/respiration $(\mathrm{P} / \mathrm{R})$ ratio. Regarding seasons, the highest $\mathrm{P} / \mathrm{R}$ ratio (1.8 \pm $0.40)$ was recorded at site (B) during winter, while the lowest one $(0.67 \pm 0.01)$ was recorded at site (A) during summer. The annual averages of $\mathrm{P} / \mathrm{R}$ ratio were $1.26 \pm 0.29$, $1.46 \pm 0.20,0.88 \pm 0.05$ and $0.92 \pm 0.06$ at site (A), (B), (C) and (D), respectively (Table 2). Production/respiration can be conveniently used for the determination of the trophic status existing at different locations and periods. The $\mathrm{P} / \mathrm{R}$ ratio demonstrates the characterized metabolic activity (oxygen production and consumption) of the community i.e $\mathrm{P} / \mathrm{R}>1$ : autotrophic community; $\mathrm{P} / \mathrm{R}<1$ : heterotrophic community (Odum1957; Vannote et al., 1980). 


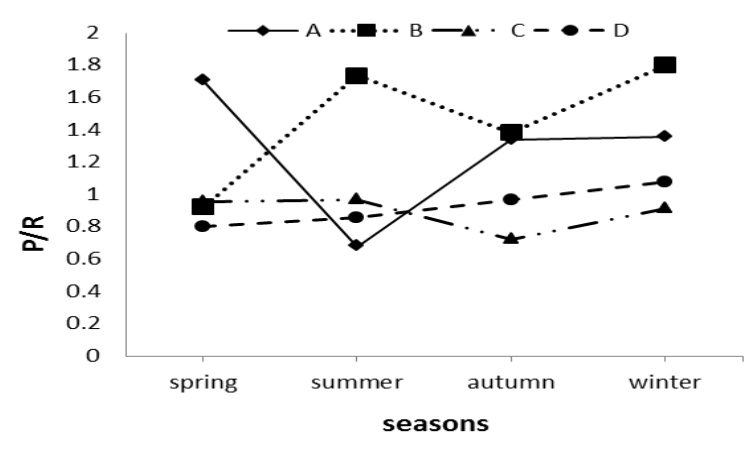

Fig. (5): Seasonal variations of gross primary productivity/respiration $(\mathbf{P} / \mathbf{R})$ ratio at the studied sites.

Net Daily Metabolism (NDM) gives an understanding of the trophic nature of the studied locations. Deviation of NDM from zero can be explained by dominance of autotrophy and heterotrophy. Fluctuations in NDM were illustrated in Figure (6). Seasonally, the highest $\left(1698 \mathrm{mgC} / \mathrm{m}^{3} / \mathrm{h}\right) \mathrm{NDM}$ was recorded at site (B) during winter, while the lowest one ($1278.8 \mathrm{mgC} / \mathrm{m}^{3} / \mathrm{h}$ ) was recorded at site (A) during summer. The annual averages of NDM were 106.6, 511.1, -599.0 and $-452.6 \mathrm{mg}$ $\mathrm{C} / \mathrm{m}^{3} / \mathrm{h}$ at site ( A, B, C and D), respectively. $\mathrm{NDM}$ is positive during periods when photosynthesis is greater than respiration (i.e, autotrophy predominates) and the system is accumulating organic matter. NDM is negative when the heterotrophy predominates with the net organic matter degradation. The average of $\mathrm{P} / \mathrm{R}$ ratio and net daily metabolism (NDM) at site (C) and (D) indicate that both of them are heterotrophic systems. On the other hand, the average of $\mathrm{P} / \mathrm{R}$ ratio and NDM at site (A) and (B) point towards autotrophy and this means that these systems produced more oxygen (organic matter) than it consumed (Table 2).

Site $\mathrm{C}$ exhibited a strong heterotrophic nature during all seasons of the study. Site B (inlet) was dominated by heterotrophic activity during spring, while during summer, autumn and winter was dominated by autotrophic activity. Site (A) was dominated by heterotrophic activity during summer, while during autumn, winter and spring was dominated by autotrophic activity. Site (D) was dominated by heterotrophic activity during spring, summer and autumn, while photosynthetic activity was dominated in winter.

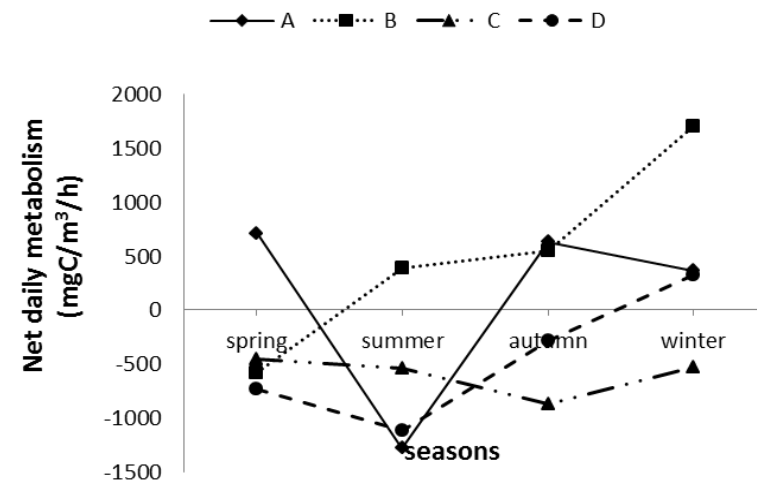

Fig. (6): Seasonal variations of net daily metabolism NDM at the studied sites.

\section{CONCLUSIONS}

It is concluded that the primary productivity and trophic nature were affected by increased levels of nutrients in fishponds, where they exhibited a strong heterotrophic nature during all the study period compared to the other sites. Fishponds are more productive than the other sites.

\section{REFERENCES}

Abd El-Monem, A.M. (2008). Impact of summer thermal stratification on depth profile of phytoplankton productivity, biomass, density and photosynthetic capacity in Lake Nasser (Egypt).Jordan Journal of Biological Science., 1(4):173-180.

Abdel-Satar, A.M.(2005).Water quality assessment of River Nile from Idfo to Cairo. Egyptian Journal of Aquatic Research., (31).2: 200-223.

Abdo, M.H. (2005).Physico-chemical characteristics of Abu Za'baal Ponds, Egypt. Egyptian J. of aquatic research., 31(2): 1- 15.

APHA (American Public Health Association), AWWA (American Water Works Association) and WEF (Water Environment Federation) (1998). Standard Methods for the Examination of Water and Wastewater $20^{\text {th }}$ Edition.United Book Press, Inc., Baltimore, Maryland.

Barnabe, G. (1994). Aquaculture biology and ecology of cultured species. Ellis Horwood Ltd.

Boyd, C.E. (1990). Water Quality in ponds for aquaculture. Alabama Agriculture Experiment Station, Auburn Univ., Alabama, USA.

Boyd C. E. (1998). Water quality for pond Aquaculture. Research and development series. International centre for aquaculture and aquatic environment, Alabama Agriculture Experiment Station, Auburn University, Alabama. 
Boyd, C. E. and Tucker, C. S. (1992). Water quality and pond soil analysis for aquaculture. Alabama agricultural experimental station. Auburn. Uni.183 pp.

Chinnaiah B. and Madhu V. (2010). Primary Productivity of Darmasagar Lake in Adilabad, Andhra Pradesh, India. International Journal of Pharmacy and Life Sciences; 1(8):437-439.

Chaurasia M. and Pandey, G. C. (2007). Study of physic- chemical characteristic of some water pond of Ayodhya-Faizabad.Indian J. of Environmental protection., 27 (11): 1019-1023.

Datta, N.C. and Badhopadhay, B.K. (1982). Studies on the Primary Productivity of a professional freshwater pond in Calcutta, India.Abstrac.1st .All India Conf.onLimnol.Nagarjuna Univ. A.P.

Devis, C.C. (1955). The Marine and Freshwater Plankton.East Canning, Michigan, State Uni. Press. 562pp.

Dytham, C. (1999). Choosing and using statistics: A Biologist's guide. Blackwell science Ltd., London, UK.

Edberg, N. and Hofsten, B.V. (1973). Oxygen uptake of bottom sediment studied in situ and in laboratory, Water Res., 7:1285-1300.

Ekubo, A. A. and Abowei, J. F. N. (2011). Review of some water quality management principles in culture fisheries, Research Journal of Applied Sciences, Engineering and Technology., 3(2): 1342-1357.

Elewa, A. A.; Saad, E. A.; Shehata, M.B. and Ghallab, M. H. (2007). Studies on the effects on the water quality of Lake Manzala, Egypt. Egypt. J. Aquat. Biol. \& Fish., 11 (2): 65- 78.

El-Otify, A.M. (2015). Evaluation of the physicochemical and chlorophyll- $a$ conditions of a subtropical aquaculture in Lake Nasser area, Egypt.Beni-Suef University Journal of Basic and Applied Sciences.4: 327-337.

Ferdoushi, Z.; Haque, F.; Khan, S. and Haque, M. (2008). The effects of two aquatic floating macrophytes (Lemna and Azolla) as biofilters of nitrogen and phosphate in fish ponds.Turk. J. Fish.and Aquatic Sci., 8: 253-258.

George, D.G. and Hurley, M.A. (2004). The influence of sampling frequency on the detection of long-term change in three lakes in the English Lake District.Aquatic Ecosystem Health and Management. 7: 1-4.

ICAR. (2011). Handbook of fisheries and aquaculture. ICAR publication, New Delhi.

Jain C.K., Bhatica K. K. S. and Vijay T. (1997). Ground water quality in coastal region of Andraapradesh. Indian J. of Env. Health. 39 (3), 182-190.
Jana, B.B.; Bag, S.K. and Rana, S. (2012). Comparative evaluation of the fertilizer value of human urine, cow manure and their mix for the production of carp fingerlings in small holding tanks.Aquaculture Internationa., 20(4): 735-749.

Jones, J.I.; Young, J.O.; Eaton, J.W. and Moss, B. (2002). The influence of nutrient loading, dissolved inorganic carbon and higher trophic levels on the interaction between submerged plants and periphyton. J. Ecol., 90: 12-24.

Karr, J.R. (1991). Biological integrity: A long-neglected aspect of water resource management. Ecological applications., 1(1): 66-84.

Khaiwal, R.; Ameena; Meenakshi; Monika; Rani and A. Kaushik. (2003). Seasonal variations in physico-chemical characteristics of river Yamuna in Haryana and its ecological best designated use. Journal of Environmental Monitoring., 5: 419426.

Khalil, M.T.; Amer, A.S.; Sayed, M.M. and Nassif, M.G. (2012). Impact of pollution on macroinvertebrates biodiversity in Ismailia Canal, Egypt. Aquat. Biol. \& Fish., 16(4): 69-89.

Maberly, S.C.; Berthelot, S.A.; Stott, A.W. and Gontero, B. (2015). Adaptation by macrophytes to inorganic carbon down a river with naturally variable concentrations of $\mathrm{CO}_{2}$. J. Plant Physiol., 172: 120-127.

McConnell, W.J.; Lewis, S. and Olson, J. E. (1988). Gross photosynthesis as an estimator of potential fish production. Trans. Amer. Fish.Soc., 106:417423.

Melack, J.M. (1976). Primary production and fish yield in tropical lakes.Trans.Amer Fish. Soc.,105 (5):580-595.

Moncrief, J.W. and Jones, W.H. (1977).Water quality management for pond fish culture.Department of Fisheries and Allied Aquaculture (ed. C.E. Boyd).Agricultural Experiment Station, Auburn, Alabama, Birmingham Publishing Company, New York.

Niusha, A.; Jamili, S. and Abdolbaghian, S. (2014). Diversity of Macrobenthos Communities and Their Relationships with Environmental Factors in Jajroud River, Iran, Resources and Environment., 4(2): 95-103.

Odum, H. T. (1957). Trophic structure and productivity of Silver Springs, Florida. Ecology Monograph 27: 55-112.

Ogbuagua, D.H., and A.A. Ayoade. (2011). Estimation of primary production along gradients of the middle course of Imo River in Etche, Nigeria. International Journal of Biosciences., 1(4): 68-73.

Prabhakar, V.M.; Vaidya, S.P.; Garud, V.S. and Swain, K.K. (2009). Trend in Primary Production 
in Khdakwasla Reservoir. $13^{\text {th }}$ World Lake Conference, Wuhan, China.

Radwan, A.M. (2005). Some Factors Affecting the Primary Production of Phytoplankton in Lake, Burulus. Egyptian Journal of Aquatic Research., 31(2):72-88.

Raina, R.; Kumar, P.; Sonaullah, F. and Wanganeo, A. (2013).Limnological study on a Smart AshokSagar with special reference to zooplankton population. International Journal of Biodiversity and Conservation., 5(6):317-332.

Rath, R. (1993). Freshwater Aquaculture.Scientific publishers, Jodhpur.

Rich, P. H. (1979). Differential $\mathrm{CO}_{2}$ and $\mathrm{O}_{2}$ benthic community metabolism in a salt-water lake. Journal of Fisheries Research Board Canada., 36: 1377-1389.

Rim-Rukeh, A.; Ikhifa, O.G. and Okokoyo, A.P. (2006). Effects of agricultural activities on the water quality of Orogodo river,Agbor Nigeria. Journal of applied sciences research., 2(5): 256259.

Ryther, J. (1956). The measurement of primary production.Limnol.Oceanogr., 1: 72 -84.

Sandjensen, K.; Pedersen, M.F. and Nielsen, S.L. (1992). Photosynthetic use of inorganic carbon among primary and secondary water plants in streams. Freshw. Biol., 27: 283-293.

Santhosh, B. and Singh, N.P. (2007). Guidelines for water quality management for fish culture in Tripura, ICAR Research Complex for NEH Region, Tripura Center, Publication no. 29

Shama, S. A.; Goher, M. E.; Abdo, M. H.; Kaial, S. M. and Ahmed, A. A. (2011). Physico-chemical characteristics and heavy metal contets in water of Wadi El-Rayan Lakes, Western desert, Egypt. Egypt. J. Aquat. Biol. And Fish., 15(2): 225- 240.

Sharma M.S. and N. Selvaraj. (2000). Heavy metal toxicity of freshwater zooplankton in relation to temperature variations. Poll Res. Vol. 19 Issue 1: 159-163.

Shiddamallayya, N. \&Pratima, M. (2008). Impact of domestic sewage on fresh water body.J. Environ. Biol., 29: 303-308.

Simmons, J.A.; Long, J.M. and Ray. J.M. (2004). What limits the productivity of acid mine drainage treatment ponds? Mine Water and the Environment, 23: 44-53.

Stewart, W. D. P.; Sinada, F.; Christof, N. and Draft, M. J. (1977). Primary production and microbial activity in Scottish freshwater habitats. In: F. A. Skinner and J. M. Shewan (eds.) Aquatic Microbiology, Academic Press, London p. 31-54.

Suberkropp, K. and Chauvet, E. (1995). Regulation of leaf breakdown by fungi in streams: influences of water chemistry. Ecology 76:1433-1445.
Takamura, N.; Zhu X.; Yang H.; Jiang X.;Li J. and Mei, Z. (1995). Characteristics of plankton communities in Chinese integrated fish ponds: effects of excessive grazing by planktivorous carps on plankton communities Hydrobiologia, 315: 211-225

Toufeek, M.E.F. and Korium, M.A. (2015). Impact of physicochemical characteristics of some Khors of lake Nasser, Egypt. Current Science International., 4(3):342.350.

Vannote, R. L.; Minshall, G. W.; Cummins, K. W.; Sedell, J. R. and Cushing, C. E. (1980). The river continuum concept.Can. J. Fish.Aquat.Sce., 37: 130-137.

Wetzel, R. G. and Likens, G. E. (2000). Limnological Analyses, 3rd. Printed by Springer Sciences, Business Media, INC. New York, USA. 429 pp.
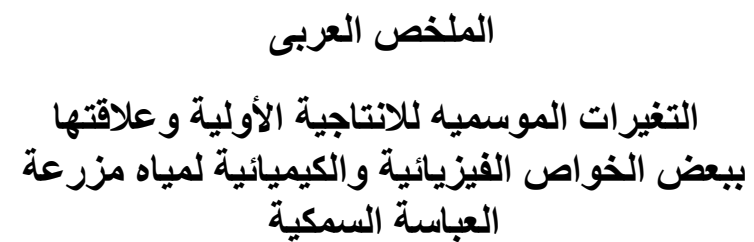

أماتى أحمد محمد*، انتصار عبدالمجيد محمد*** سمير محمد

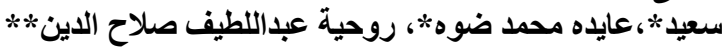
*قسم اللينولوجى ـ الدعل المركزى لبحوث الثروه السككبه

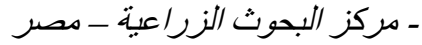

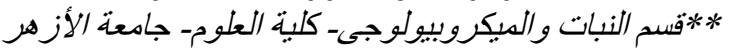
(فرع البنات) - مدينة نصر - القاهرة - مصر معر الان

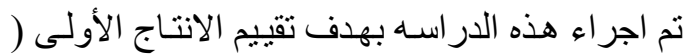

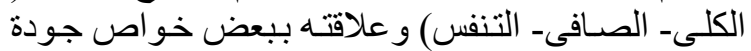

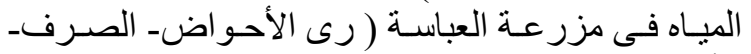

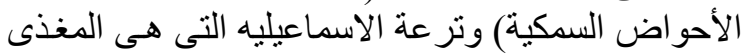

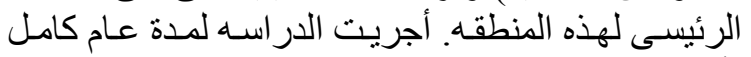

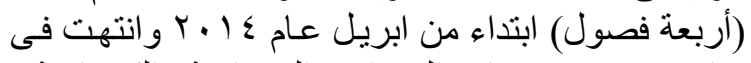

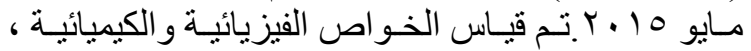

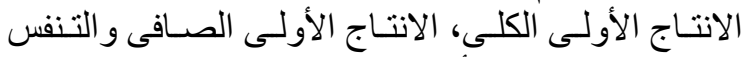

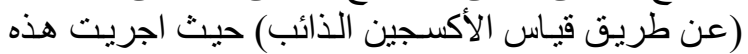

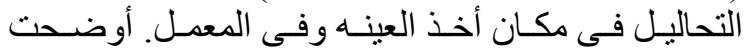

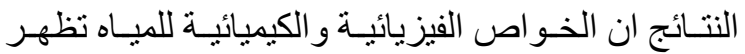
اختلافا معنويا بين المواسم والمواقع محل الدراسه .

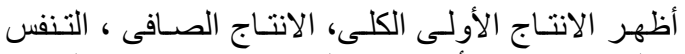

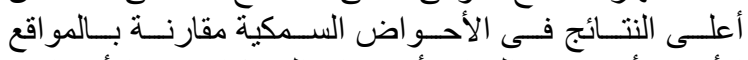

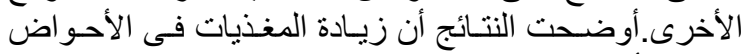

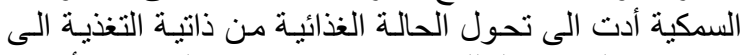

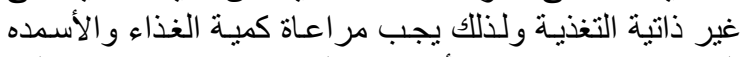

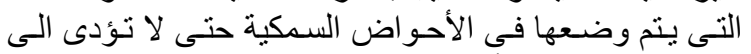
مشاكل (كالتنفس) للأسماك المرباة. 